\title{
Response of a Mediterranean phytoplankton community to increased nutrient inputs: a mesocosm experiment
}

\author{
Carlos M. Duarte*, Susana Agustí, Nona S. R. Agawin \\ Instituto Mediterráneo de Estudios Avanzados (CSIC-UIB), C/ Miquel Marqués, 21, 07190 Esporles, Mallorca, \\ Islas Baleares, Spain
}

\begin{abstract}
The response of the biomass and primary production of a coastal NW Mediterranean phytoplankton community to a gradient of nutrient inputs was examined in a large-scale mesocosm nutrient enrichment experiment over a period of $20 \mathrm{~d}$ in summer. The mesocosm units $\left(33 \mathrm{~m}^{3}\right)$ received $\mathrm{N}, \mathrm{P}$ and $\mathrm{Si}$ at a stoichiometric ratio of $20 \mathrm{~N}: 7 \mathrm{Si} 1 \mathrm{P}$, at the normal nutrient loading rate at the site $\left(5 \mathrm{mmol} \mathrm{N} \mathrm{m} \mathrm{N}^{-2} \mathrm{~d}^{-1}\right.$ and $0.25 \mathrm{mmol} \mathrm{P} \mathrm{m} \mathrm{m}^{-1}$ ), and at $0.5,2,4,8$ and 16 times the normal nutrient loading rate. The biomass and production of the phytoplanktonic community was also examined in a mesocosm unit to which no nutrients were added. Substantial differences in phytoplankton biomass were observed 4 to $12 \mathrm{~d}$ after the initiation of the experiment, when nutrient inputs were increased more than 4 -fold above the normal nutrient loading rate. The blomass of the community increased to a maximum of $40.8 \mathrm{\mu g}$ chlorophyll a $\mathrm{l}^{-1}(200$-fold above the mean initial value) at the greatest nutrient inputs. The biomass increase was largely attributable to an increase in the microphytoplankton biomass (Chaetoceros sp. and Licmophora sp.), while picophytoplankton increased their biomass only during the earlier phase of the experiment, reaching values 4.7 times greater at the highest nutrient addition than at the normal loading rate. The structure of the phytoplankton community shifted from an initial dominance of picophytoplankton to dominance of microphytoplankton at the highest nutrient loadings. Primary production increased in response to increased nutrient loading, reaching a level 10 -fold higher at the highest nutrient loading than at the normal loading rate. However, phytoplankton carbon turnover did not increase significantly with increasing loading $(p>0.05)$, except for a tendency for higher turnover at the highest nutrient inputs tested. Results from this experiment suggest that eutrophication problems are likely to become important at a loading of more than 4 -fold higher $\left(20 \mathrm{mmol} \mathrm{N} \mathrm{m} \mathrm{m}^{-2} \mathrm{~d}^{-1}\right.$ and $1 \mathrm{mmol}$ $P \mathrm{~m}^{-2} \mathrm{~d}^{-1}$ ) than the present values supplied to the coastal Mediterranean community studied.
\end{abstract}

KEY WORDS: Plankton - Nutrient inputs - Mediterranean - Biomass - Production - Response

\section{INTRODUCTION}

Increased human pressure in the Mediterranean Sea is responsible for major changes in coastal zone ecosystems (Duarte et al. 1999). Rapid increase in the human population, both resident (132 million in 1985, doubling time $32 \mathrm{yr}$, UNEP 1989) and seasonal (107 million in 1987, doubling time $15 \mathrm{yr}$, UNEP 1989) along the Mediterranean coastline has led to increased nutrient inputs, particularly along its northern shore (UNEP

\footnotetext{
•E-mail: ieacdq@clust.uib.es
}

1989). Because Mediterranean phytoplankton communities are believed to be phosphorus limited (Krom et al. 1991, Thingstad \& Rassoulzadegan 1995, Thingstad et al. 1998), it is not surprising that symptoms of eutrophication are now becoming widespread in the coastal Mediterranean Sea (e.g. Marchetti 1992, Duarte et al. 1999).

The occurrence of nuisance mucous substances, foam and oxygen deficiency caused by diatoms and nanoplankton in the Adriatic Sea have been attributed to increased nutrient inputs there (Degobbis 1989, Dederen 1992, Marchetti 1992). The frequency of red tides in the Mediterranean appears to have increased 
(UNEP 1989), and widespread deterioration of water quality, as reflected in reduced water transparency, has been reported (e.g. Marbá \& Duarte 1997). However, studies of eutrophication processes in the Mediterranean Sea are still few, lagging well behind those in Atlantic waters (Vidal et al. 1999)

The regulation of nutrient inputs into the coastal zone requires quantitative knowledge on the response of phytoplankton communities to increased nutrient inputs. This knowledge allows the elucidation of the resilience of the communities to nutrient inputs, and, thereby, the definition of critical nutrient loading ratios. These aspects of the response of phytoplankton communities to nutrient inputs have been successfully examined in the past through the use of mesocosm experiments (e.g. Nixon et al. 1986). However, these experiments have largely focused on Atlantic waters (e.g. Oviatt et al. 1989, Hein \& Riemann 1995, Escaravage et al. 1996), and we are not aware of mesocosm experiments addressing the response of Mediterranean phytoplankton to a gradient of nutrient additions. Knowledge derived from experiments in Atlantic coastal waters may not be directly applicable to Mediterranean waters, as their planktonic communities are dominated by nano- and microplankton (e.g. Oviatt et al. 1989, Ray et al. 1989, Tremblay \& Legendre 1994) and picoplanktonic (e.g. Agawin et al. 1998) organisms, respectively. These food webs are characterised by contrasting controls (Legendre \& Rassoulzadegan 1995), so that their response to nutrient inputs may well differ. There is, therefore, a need to experimentally establish the resilience of Mediterranean phytoplankton communities to increased nutrient inputs.

We examine here the response of the biomass and primary production of a coastal NW Mediterranean phytoplankton community to increased nutrient inputs. The response of the community to a gradient of nutrient inputs, extending above and below those presently realised in the coastal ecosystem studied, was tested in a set of large (effective volume $33 \mathrm{~m}^{3}$ ) mesocosm units suspended in the Bay of Blanes (NE Spain).

\section{METHODS}

The experiment was conducted near the town of Blanes (NE Spain), the population of which and, consequently, nutrient loading to the sea, increases by about 5 times during the summer season (Duarte et al. 1999). Nutrient budgets, calculated on the basis of estimates of nutrient loading and sedimentation rates, have established the nutrient loading to Blanes Bay to be about $5 \mathrm{mmol} \mathrm{N} \mathrm{m}^{-2} \mathrm{~d}^{-1}$ and $0.25 \mathrm{mmol} \mathrm{P} \mathrm{m} \mathrm{m}^{-2} \mathrm{~d}^{-1}$ in summer (Duarte unpubl. results). This loading is clearly dominated by anthropogenic sources, so that the stoichiometry between N, P and Si inputs observed (20 N:7 Si:1 P, Duarte unpubl. results) represents that derived from human intervention. Further increases in nutrient loading will most likely retain the present stoichiometry. We used the estimate of the summer nutrient loading in Blanes Bay, hereafter referred to as a 'business as usual' control, to scale the nutrient inputs to the experimental mesocosms. Phosphorus and silicon were added to maintain their average summer stoichiometry with nitrogen in the sedimentary flux (20 N:7 Si:1 P, Duarte unpubl. results). Nitrogen was added as ammonium, the dominant form of summer nitrogen inputs to Blanes Bay (Duarte unpubl. data).

The experiment was conducted between 18 June and 8 July 1997. We used a series of 7 large (nominal and effective volume 50 and $33 \mathrm{~m}^{3}$, respectively) mesocosms designed following the CEPEX enclosures (Menzel \& Case 1977). The mesocosms consisted of $14 \mathrm{~m}$ high UV-stabilised polyethene bags, $4.2 \mathrm{~m}^{2}$ in cross-sectional area at their opening and closed by a $2 \mathrm{~m}$ tall conical piece. The mesocosms, mounted on a floating platform, were moored at $35 \mathrm{~m}$ depth, at about $2 \mathrm{~km}$ offshore from the town of Blanes. This coastline is rather exposed, and subject to substantial wave action (Cebrián et al. 1996, Duarte et al. 1999), so that the $35 \mathrm{~m}$ deep water column at the study site is well mixed throughout the summer, and no measurable thermal stratification occurs in the layer occupied by the mesocosm units (Cebrián et al. 1996). The mesocosms were set up the day preceding the initiation of the nutrient addition, and were filled by gravity, followed by the use of a water pump. The bags were only partially filled to prevent rupture due to wave action and to allow the propagation of turbulence across the walls of the mesocosm units, thereby maintaining well-mixed conditions. The mixing time of water in the mesocosm units was determined experimentally, through dye additions at the end of the study. It was on the order of 5 to $10 \mathrm{~min}$ on a relatively calm day. The experimental period was characterised by unusual wave action for the summer period, so that the units were inspected regularly by SCUBA divers to check for damage. One of the units (which was receiving twice the "business as usual' nutrient loading) was found to be damaged $4 \mathrm{~d}$ prior to the end of the experiment.

The experiment had a gradient design, including progressive nutrient additions to 7 mesocosm units, which allowed the response of phytoplankton to increasing nutrient inputs to be described using regression analysis (Nixon et al. 1984). Nutrient additions were implemented using solutions of $\mathrm{ClNH}_{4}$, $\mathrm{KH}_{2} \mathrm{PO}_{4}$, and $\mathrm{Na}_{2} \mathrm{SiF}_{6}$, in seawater. The nutrient additions included a treatment equivalent to the 'business as usual' control, a treatment equivalent to half of that 
nutrient input, and nutrient additions equivalent to $2,4,8$ and 16 times the 'business as usual' control (Table 1). In addition, we also followed the biomass and primary production of the phytoplankton community present in a mesocosm to which no nutrients were added. The nutrient input to this mesocosm unit, derived from wet and dry atmospheric deposition, was determined from short-term nutrient mass balances to be about $0.005 \mu \mathrm{M} \mathrm{N} \mathrm{d} \mathrm{N}^{-1}$ (Duarte et al. unpubl. data).

Samples to determine nutrient concentrations, phytoplankton biomass and primary production were collected on alternate days at 07:00 h. Since the water column was well mixed, as confirmed by CTD profiles obtained at noon during the experiment, integrated water samples $(0$ to $13 \mathrm{~m})$ were collected. The water samples were transported, within $30 \mathrm{~min}$ to the laboratory for analysis. Nutrients were added to the mesocosms on alternate days, following the collection of samples. In order to ensure adequate mixing, nutrient additions were conducted by filling a tube extending from the water surface to the bottom of the mesocosms, which was slowly withdrawn to ensure homogeneous distribution along the water column.

The concentrations of dissolved inorganic phosphate, ammonium and silicate were measured spectrophotometrically following standard methods (Koroleff $1976 \mathrm{a}, \mathrm{b}, \mathrm{c})$, using a $10 \mathrm{~cm}$ cuvette cell when necessary to increase the detection limit. A variable water volume (50 to $500 \mathrm{ml}$, depending on phytoplankton biomass) was filtered through Whatman GF/F filters for fluorometric analysis of chlorophyll a concentration (Parsons et al. 1984). The filters were homogenised and kept refrigerated in the dark while pigments were extracted in $90 \%$ acetone for ca 6 h. Following extraction, fluorescence was measured in a Turner Designs fluorometer calibrated with pure chlorophyll a (Sigma Co.). Primary production, based on ${ }^{14} \mathrm{C}$ incorporation rates of the picoplankton fraction and whole sea water, was determined in each mesocosm every 4 to $5 \mathrm{~d}$ after initiation of the experiment (cf. Agawin et al. in press). A $500 \mathrm{ml}$ volume was withdrawn from each mesocosm unit and was filtered through $2 \mu \mathrm{m}$ (pore size) polycarbonate filters. Three (2 clear and 1 dark) $125 \mathrm{ml} \mathrm{PC}$ Nalgene bottles were each filled with $120 \mathrm{ml}$ of the picoplankton fraction, while another set of 3 bottles was filled with whole sea water from the same mesocosm. One millilitre of ${ }^{14} \mathrm{C}$ solution was added to each bottle in varying concentrations $(23,20,15,10,5 \mu \mathrm{Ci})$, depend- ing on the increase in phytoplankton biomass and carbon uptake expected. The light and dark bottles were incubated for $3 \mathrm{~h}$ at $200 \mu \mathrm{E} \mathrm{m} \mathrm{m}^{-2} \mathrm{~s}^{-1}$ in an incubator chamber with temperature control (adjusted to the in situ water temperature). After incubation, samples were filtered through $0.45 \mu \mathrm{m}$ Millipore filters, and filters were fumed over concentrated $\mathrm{HCl}$ to remove traces of inorganic C. Radioactivity on the filters was measured with a liquid scintillation counter, with correction for quenching. All materials were acid-cleaned prior to use. Primary production estimates were converted to daily rates by multiplying the hourly rates by 14 daylight hours. Because the light climate was not simulated, the calculated daily production may deviate from the values obtained in situ, but we expect the deviations to be minimal, since the average underwater irradiance exceeded, during most of the day, the values needed to saturate photosynthesis $\left(<200 \mu \mathrm{E} \mathrm{m} \mathrm{m}^{-2} \mathrm{~s}^{-1}\right.$ in summer, Satta et al. 1996).

The abundance of autotrophic plankton was estimated using flow cytometry for picoplankton, epifluorescence microscopy for nanoflagellates, and an inverted microscope for microphytoplankton. Fresh subsamples of water from the different experimental bags were filtered through a $50 \mu \mathrm{m}$ mesh, maintained in the dark and analysed in a FACSCalibur (Becton Dickinson) flow cytometer for the quantification of picophytoplanktonic cells (Agustí et al. unpubl, data). Cell volume was estimated from the mean cell diameter, calculated from the mean forward scattering signal of the populations and calibrated against the diameter of commercial fluorescent beads (FluoSpheres Size Kit No. 2, Molecular Probes Co.).

Nanophytoplankton samples, preserved in glutaraldehyde ( $1 \%$ final concentration) were filtered onto $0.6 \mu \mathrm{m}$ Nuclepore filters and counted and mea- 
sured at $1000 \times$ magnification under an epifluorescence microscope. Microphytoplanktonic samples $(0.5$ to $2 l_{1}$ depending on density), preserved in glutaraldehyde ( $1 \%$ final concentration), were pre-concentrated using a Millipore concentrator chamber and were enumerated and counted at $200 \times$ and $320 \times$ magnification under an inverted microscope (Agustí et al. unpupl.
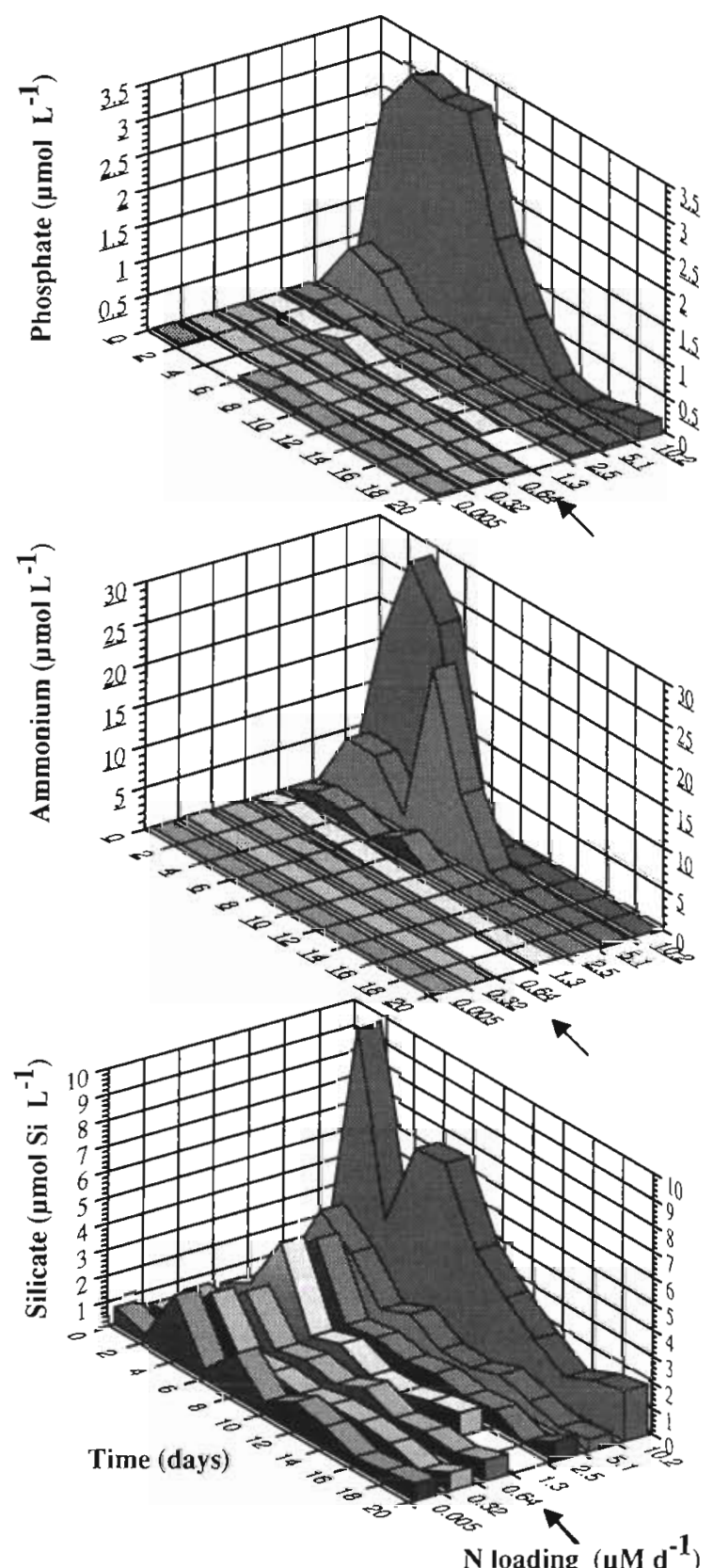

Fig. 1. Evolution of dissolved inorganic nutrient concentration in response to increased nutrient inputs to the mesocosms. The arrow indicates the nutrient loading corresponding to the 'business as usual' scenario in Blanes Bay data). Cell volume was calculated from microscope measurements of the linear dimensions of the cells. Phytoplankton biovolume was calculated as the product of cell abundance and the cell volume of at least 30 cells in each taxon counted. Autotrophic carbon was calculated from biovolume estimates by assuming cyanobacteria to contain $0.123 \mathrm{pg} \mathrm{C} \mu \mathrm{m}^{-3}$ (Waterbury et al. 1986), and using the equations provided by Strathmann (1967) for the other groups.

\section{RESULTS}

Nutrient concentrations at the onset of the experiment were very low (dissolved inorganic nitrogen $<0.05 \mu \mathrm{M}$, phosphate $=0.01 ;$ Fig. 1), among the lowest
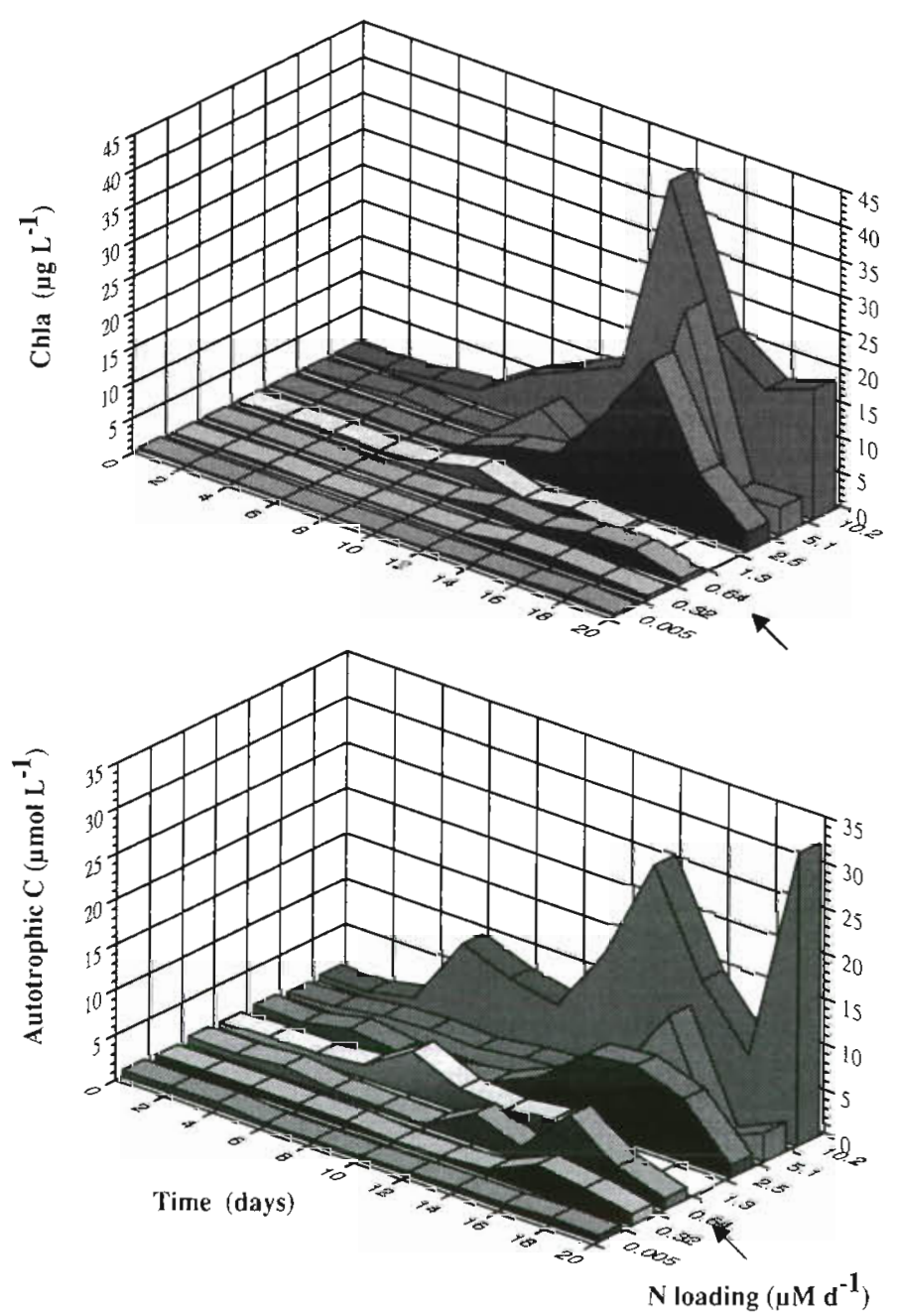

Fig. 2. Evolution of the abundance of planktonic autotrophs, expressed both as chlorophyll a concentrations and autotrophic carbon values, in response to increased nutrient inputs to the mesocosms 
values recorded during a 7 yr monitoring programme in Blanes Bay (Duarte unpubl data). The nutrients added were rapidly assimilated by the community, so that nutrient accumulation was only observed after increasing nutrient inputs 4 (for ammonium) to 8 (for phosphate) fold above the 'business as usual' value (Fig. 1). Silicate concentrations at the onset of the experiment were low (about $0.5 \mu \mathrm{M}$ ), and accumulated in most mesocosms during the first half of the experiment, being subsequently reduced by diatom uptake. After a delay of 4 to $8 \mathrm{~d}$, the communities present in the mesocosms receiving $>4$ and $>8$ times the nutrient inputs received at the Bay were also able to assimilate the inorganic nutrients accumulated, so that by the end of the experiment nutrient concentrations were low ( $<0.1$ for ammonium, $<0.2 \mu \mathrm{M}$ for phosphate, $<2 \mu \mathrm{M}$ for silicate) in all mesocosms (Fig. 1).

The phytoplankton community responded to increased nutrient inputs by increasing its biomass, reaching a maximum chlorophyll a concentration of $40.8 \mathrm{\mu g} \mathrm{l}^{-1}$ in the mesacosm receiving the highest nutrient inputs (Fig. 2). Chlorophyll a concentration increased 4 to $12 \mathrm{~d}$ after the initiation of the experiment, depending on the mesocosms, and the differences in chlorophyll a concentration only became substantial after nutrient inputs were increased $>4$ times (Fig. 2). The increased biomass of the autotrophic community in response to increased nutrient inputs was also evident in the community carbon (Fig. 2). The increase in autotrophic carbon preceded that of chlorophyll $a_{i}$ as a result of the tendency for the carbon to chlorophyll ratio to decline with increased nutrient loading $(r=0.80, p<0.01)$, likely resulting from the increased self shading as autotrophic biomass accumulated.

The autotrophic community enclosed was originally dominated by picoplankton (Fig. 3), represented exclusively by Synechoccocus sp., which comprised $51 \pm$ $4 \%$ of the autotrophic carbon at the onset of the experiment. Synechoccocus sp. showed an early (about $4 \mathrm{~d}$ following nutrient additions) increase in response to nutrient additions, reaching a biomass 4.7 -fold greater than that in the 'business as usual' mesocosm at the highest nutrient addition (Fig. 3). Synechoccocus sp carbon declined subsequently to remain at levels comparable to those in the 'business as usual' mesocosm during most of the experiment (Fig. 3). Autotrophic nanoflagellates, which represented $8.5 \pm 2.1 \%$ of the original autotrophic carbon, showed a late but sudden biomass increase at the highest nutrient loading, reaching their highest biomass at about $16 \mathrm{~d}$ following the initiation of nutrient additions (Fig. 3).

The biomass increase of the autotrophic community was largely attributable to an increase in the biomass of microphytoplankton (Fig. 3). In turn, this response derived from an increase in the biomass of diatoms, which comprised $40.0 \pm 5.3 \%$ of the autotrophic carbon at the onset of the experiment, with increasing nutrient inputs (Fig. 3). The response of diatoms, where Chaetoceros sp. and Licmophora sp. were the most important taxa, was most evident at the highest nutrient input tested, which led to increased abundance only $6 \mathrm{~d}$ following enrichment, compared to biomass increases after about $8 \mathrm{~d}$ to $2 \mathrm{wk}$ in the other treat-

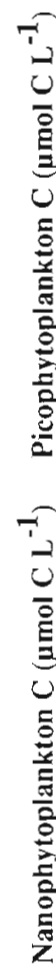

U)
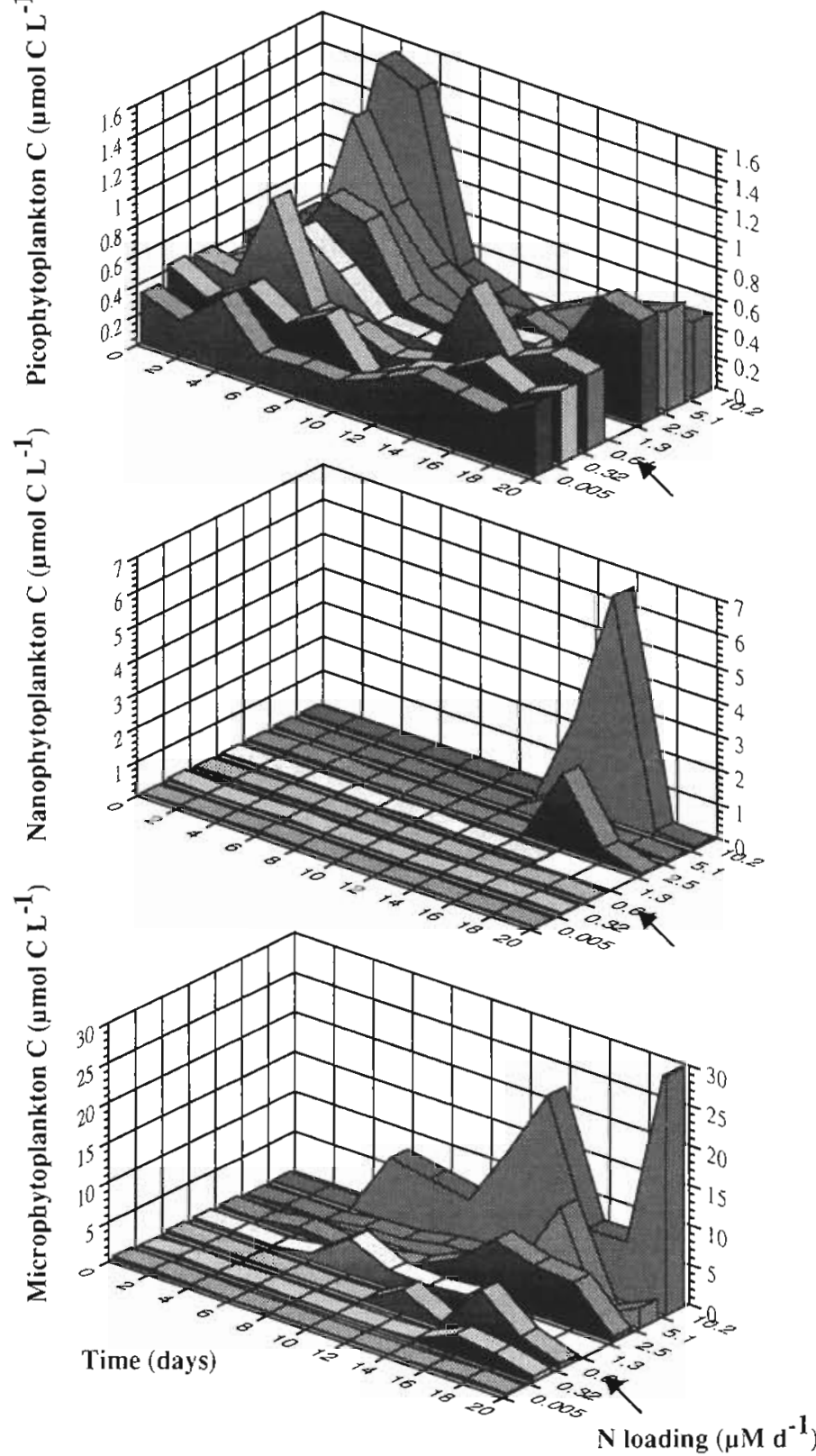

Fig. 3. Evolution of the biomass of different components of the autotrophic community in response to increased nutrient inputs to the mesocosms 

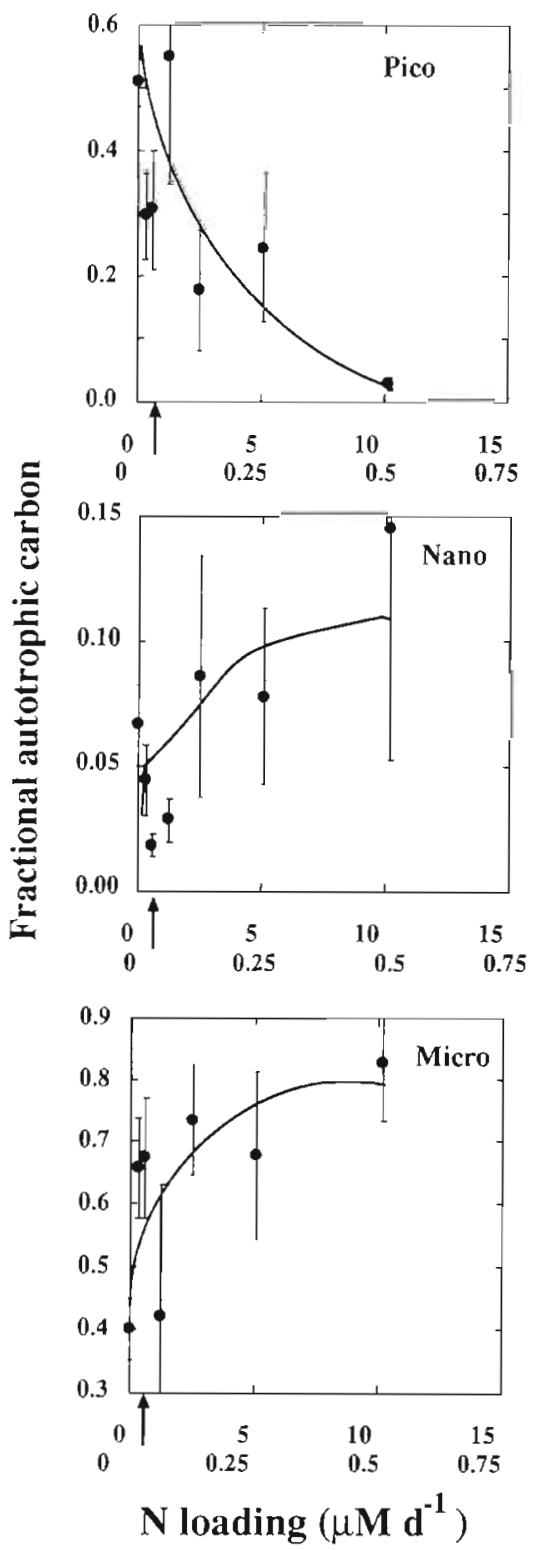

P loading $\left(\mu \mathbf{M ~ d}^{-1}\right)$

Fig. 4. Average (Days 14 to 20 after the initiation of the experiment) contribution of picoplankton, autotrophic nanoflagellates, and diatoms and dinoflagellates (Micro) to the phytoplankton biomass in relation to nutrient inputs to the mesocosms. Error bars represent the standard error of the average values

ments (Fig. 3). As a result of these changes, the community experienced a shift in structure, from an initial dominance of Synechococcus sp. in the original community, to a dominance of microphytoplankton at the highest nutrient loadings (Fig. 4).

Primary production rose in response to increased nutrient loading, although this rise was not observed until at least a week following nutrient additions
(Fig. 5). Primary production increased in all enriched bags, including those receiving nutrient inputs equal to or half of the 'business as usual' values. The maximum primary production reached in the mesocosm receiving the highest nutrient dosage was 10-fold higher than that in the 'business as usual' mesocosm (Fig. 5).

The mean and maximum phytoplankton carbon and primary production in the mesocosms increased significantly in response to nutrient additions ( $r=0.90$ and 0.88 , respectively, for phytoplankton carbon, and $\mathrm{r}=$ 0.95 and 0.98 for primary production, $p<0.005$; Fig. 6). Yet, these responses were clearly non-monotonous, as a statistically significant increase over the mean 'business as usual' primary production was only observed when nutrient inputs were increased $>8$-fold over the mean summer value in Blanes Bay (Tukey's HSD test, $p<0.001$; see also Fig. 6). That a significant rise in average production was observed only at nutrient enrichment $>8$ times the 'business as usual' values implies that the responses were somewhat obscured by the fluctuations, since non-parametric analyses showed a consistent tendency for primary production to be greater with nutrient inputs $>4$ times above normal values (Wilcoxon sign-ranked test, $\mathrm{p}<0.05$ ).

Primary production increased proportionately to increasing phytoplankton biomass ( $\mathrm{r}=0.98, \mathrm{p}<0.001)$. This indicated that the turnover of phytoplankton carbon (mean carbon $\pm \mathrm{SE}=6.4 \pm 1.3 \mathrm{~d}^{-1}$ among the mesocosms) did not vary significantly with increasing nutrient loading ( $r=0.53, p=0.21$; Fig. 6), despite a tendency for it to be faster at the highest nutrient loading tested.

\section{DISCUSSION}

Increased nutrient inputs led to an initial increase of the dominant population originally present in Blanes Bay, resulting in the maximum cyanobacteria biomass being reached about $4 \mathrm{~d}$ following nutrient inputs. This strongly suggests that the natural phytoplankton community in Blanes Bay was nutrient limited, consistent with the very low nutrient concentration at the start of the experiment. Nutrient limitation of summer Mediterranean phytoplankton communities has been reported in the past, and phosphorus (Jacques et al. 1973. Fiala et al. 1976, Krom et al. 1991, Vaulot et al. 1996, Thingstad et al. 1998), but also nitrogen (Owens et al. 1989) were identified as the limiting nutrients.

The calculations of phytoplankton turnover time suggest that reduced losses probably supported most of the responses at intermediate nutrient inputs, whereas at high nutrient inputs enhanced growth rates were also involved. These results are consistent with reports from 
previous research on marine mesocosms, which have shown that the development of phytoplankton blooms in response to moderately increased nutrient additions cannot be ascribed to increased growth rates (Hein \& Rieman 1995, Schlüter 1998). This conclusion is consistent with the finding that phytoplankton populations appear to be controlled by losses, rather than limitation of growth rate, in the NW Mediterranean coastal area studied (Mura et al. 1996b). For instance, loss rates of picophytoplankton have been shown to be closely coupled to their production in Blanes Bay (Agawin et al. 1998, in press), whereas grazing on microphytoplankton appears to remove only a modest $(<30 \%$, Alcaraz unpubl. data) fraction of their production. In addition, phytoplankton mortality has been shown to be very high in the NW Mediterranean, particularly in summer (Agustí et al. 1998, Agustí \& Duarte in press).

The phytoplankton biomass in Blanes Bay was small (mean chlorophyll a concentration $=0.02 \mu \mathrm{g} \mathrm{l}^{-1} \mathrm{j}$, characteristic of the summer season despite the already high nutrient inputs of about $5 \mathrm{mmol} \mathrm{N} \mathrm{m}^{-2} \mathrm{~d}^{-1}$ and $0.25 \mathrm{mmol} \mathrm{P} \mathrm{m} \mathrm{m}^{-2} \mathrm{~d}^{-1}$ (Duarte et al. 1999). Similar nutrient inputs lead, however, to the development of highly productive phytoplankton communities in Atlantic waters (Borum 1996, Boynton et al. 1996), where they are sufficient to cause eutrophication problems (Kemp et al. 1983, Dennison 1987, Boynton et al. 1996). In contrast, a significant increase in biomass and primary production of the NW Mediterranean phytoplankton community investigated was only observed after nutrient inputs were increased more than 4 -fold over the 'business as usual' loading. Hence, the plankton community investigated was able to assimilate nutrient inputs far exceeding the summer loading at Blanes Bay, which is already considerable. The results from this short-term experiment suggest that the critical nutrient load, at which phytoplankton biomass accumulates and eutrophication problems are likely to become important, is on the order of $20 \mathrm{mmol}$ $\mathrm{N} \mathrm{m}^{-2} \mathrm{~d}^{-1}$ or $1 \mathrm{mmol} \mathrm{P} \mathrm{m}^{-2} \mathrm{~d}^{-1}$, at the $\mathrm{N}$ :P:Si loading ratios observed in Blanes Bay. Since eutrophication symptoms are observed at nutrient loadings well below this level in Atlantic waters, these results suggest that critical nutrient loadings are higher for Mediterranean coastal plankton communities than they are for Atlantic ones. This suggestion would, if confirmed, have important consequences in setting management goals for Mediterranean waters and should, therefore, be tested further.

The reason for such differences, if confirmed, are unclear, but probably result from the high losses

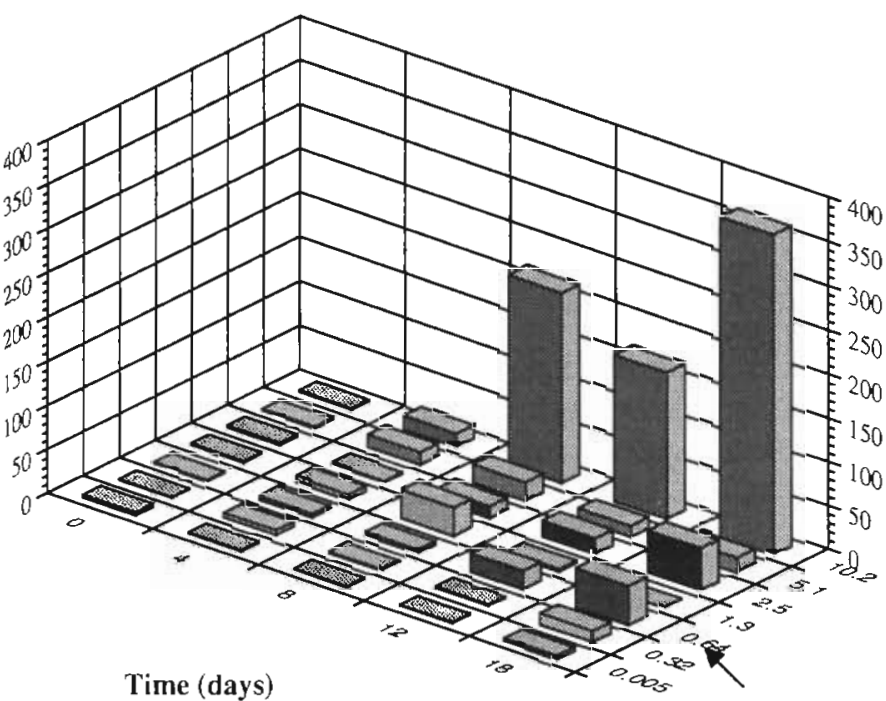

$\mathrm{N}$ loading $\left(\mu \mathrm{M} \mathrm{d}^{-1}\right)$

duction in response to increased nutrient inputs

experienced by Mediterranean phytoplankton (Mura et al. 1996b, Agawin et al. 1998, Agustí et al. 1998), which may prevent them from accumulating to reach the biomass levels observed in Atlantic waters. Mediterranean phytoplankton communities are dominated by pico- and nanoplankton, which are efficiently grazed by protozoans and gelatinous plankton (e.g. Agawin et al. 1998). In addition, an important fraction of the primary production is released as dissolved organic matter through lysis of phytoplankton cells (Agustí et al. 1998, Agustí \& Duarte in press). In contrast, phytoplankton losses appear to be lower in Atlantic waters, such as the much lower cell lysis rates reported in Atlantic waters, even during bloom collapse (van Boekel et al. 1992, Brussaard et al. 1995).

The differences may also be partially attributable to differences in the nature of nutrient limitation, for while $\mathrm{N}$ appears to be the main limiting element in Atlantic waters, Mediterranean plankton appears to be $\mathrm{P}$ limited (Krom et al. 1991, Thingstad \& Rassoulzadegan 1995, Thingstad et al. 1998). The role of $N$ versus $P$ limitation in controlling phytoplankton development cannot be properly addressed here. since this experiment used a constant $\mathrm{N}$ to $\mathrm{P}$ input ratio.

Human pressure on the Mediterranean Sea has been increasing rapidly over this century as a consequence of rapid population growth (UNEP 1989, Duarte et al. 1999). Nutrient loading to the Mediterranean coastline has increased in parallel (e.g. Duarte et al. 1999), and is now comparable to or exceeds the values observed in 
areas affected by severe eutrophication problems along the Atlantic coast (Borum 1996, Boynton et al. 1996). Yet, phytoplankton biomass remains relatively low throughout most of the Mediterranean coastal areas (e.g. Yilmaz et al. 1992, Mura et al. 1996a), but eutrophication problems are becoming apparent, particularly in areas with excessive nutrient loading and/or re- stricted water exchange. Severe problems have occurred in the northern Adriatic Sea, where nutrient loading exceeds $123 \times 10^{6} \mathrm{~kg} \mathrm{~N} \mathrm{yr}^{-1}$ (Provini et al. 1992), and, even in areas where water quality remains good, symptoms of deterioration are evident. For instance, water transparency on the NE Spanish coast has declined at a rate of $0.1 \mathrm{~m} \mathrm{yr}^{-1}$ over the past 3 decades (Marbá \& Duarte 1997), and widespread loss of seagrasses, which are very sensitive to changes in water quality (Duarte 1991), has been documented (Marbá \& Duarte 1997). Indeed, phytoplankton development was reduced when nutrient loading rates below the 'business as usual' scenario were applied, suggesting that phytoplankton development can be reduced by controlling nutrient inputs, which may help restore the transparency levels and the seagrass growth observed decades ago.

The results reported here suggest that the response of phytoplankton biomass and production to nutrient loading is not linear, but rather that abrupt changes occur once the critical nutrient threshold is exceeded. Hence, although the critical nutrient loadings required to cause algal blooms in Blanes Bay appear to be high, the apparent high resilience of these communities must be tested on time scales much longer than $20 \mathrm{~d}$ before permissive critical nutrient loadings are proposed. This is partirularly important because, althougn the abrupt responses expected when critical nutrient loadings are exceeded are not widespread in the NW Mediterranean as yet, symptoms of eutrophication, such as a gradual loss of transparency in coastal waters, are becoming apparent. Moreover, the resilience of NW Mediterranean phytoplankton communities to high nutrient loadings appears to involve the control exerted by high loss rates. The response of these loss factors, including grazing and mortality (Mura et al. 1996b, Agustí et al. 1998, Agustí \& Duarte in press), to nutrient loading must also be investigated before reliable critical levels can be formulated.
Fig 6. Relationship between the mean and maximum values of primary production, autotrophic carbon, and turnover of autotrophic carbon, and nutrient inputs to the mesocosms. The arrow indicates the 'business as usual' loading to the experimental site 
Acknowledgements. This is a contribution to the project COMWEB, funded by the ELOISE programme of the European Commission (contract number MAS3-CT96-0045), and a grant from the Spanish Commission for Science and Technology. We thank M. C. Sánchez for assistance with phytoplankton counts, A. Lucea for nutrient analyses, $O$. Moreno for chlorophyll a analyses, J. Seppala, T. Tamminen, and the staff at Tallers FERM (Blanes, Spain) for advice in the design and construction of the mesocosms, A. Juán Sr and Jr for assistance with the operation of the mesocosms, and the Blanes Peix company for permission to deploy the platform in their concession. N.S.R.A. was supported by a fellowship of the Agencia Española de Cooperación Internacional

\section{LITERATURE CITED}

Agawin NSR, Duarte CM, Agustí S (1998) Growth and abundance of Synechococcus sp. in a Mediterranean bay: seasonality and relationship with temperature. Mar Ecol Prog Ser 170:45-53

Agawin NSR, Duarte CM, Agustí S (in press) Nutrient and temperature control of the contribution of picoplankton to phytoplankton biomass and production. Limnol Oceanogr

Agustí S, Duarte CM (in press) Strong seasonality in phytoplankton cell lysis in the NW Mediterranean littoral. Limnol Oceanogr

Agustí S, Satta MP, Mura MP, Benavent E (1998) Dissolved esterase activity as tracer of phytoplankton lysis: Evidence of high phytoplankton lysis rates in the NW Mediterranean. Limnol Oceanogr 43:1836-1849

Bethoux JP, Morin P, Madec C, Gentili B (1992) Phophorus and nitrogen behaviour in the Mediterranean Sea. DeepSea Res 39:1641-1654

Borum J (1996) Shallow waters and land/sea boundaries. In: Jørgensen BB, Richardson K (eds) Eutrophication in coastal marine ecosystems. Coastal and estuarine studies. Vol 52. American Geophysical Union, Washington, DC, p 179-203

Boynton WR, Murray L, Hagy JD, Stokes C, Kemp WM (1996) A comparative analysis of eutrophication patterns in a temperate coastal lagoon. Estuaries 19:408-421

Brussaard CPD, Riegman R, Noordeloos AAM, Cadée GC, Witte H, Kop AJ, Nieuwland G, Guyl FC, Bak RPM (1995) Effects of grazing, sedimentation and phytoplankton cell lysis on the structure of a pelagic food web. Mar Ecol Prog Ser 93:39-48

Cebrián J, Duarte CM, Pascual J (1996) Marine climate in the NW Mediterranean littoral. In: Duarte CM (ed) Seasonality in the Blanes Bay: a paradigm of the northwest Mediterranean littoral. Publ Espec Inst Esp Oceanogr 22:9-21

Dederen LHT (1992) Marine eutrophication in Europe: similarities and regional differences in appearance. Sci Total Environ 1992(Suppl):663-672

Degobbis D (1989) Increased eutrophication of the northern Adriatic Sea. Mar Pollut Bull 20:452-457

Dennison WC (1987) Effects of light on seagrass photosynthesis and depth distribution. Aquat Bot 27:15-26

Duarte CM (1991) Seagrass depth limits. Aquat Bot 40 : $363-377$

Duarte CM, Agustí S, Kennedy H, Vaqué D (1999) The Mediterranean climate as a template for the Mediterranean marine ecosystem: the example of the NE Spanish littoral. Prog Oceanogr 44:245-270

Escaravage V, Prins TC, Smaal AC, Peeters JCH (1996) The response of phytoplankton communities to phosphorus input reduction in mesocosm experiments. J Exp Mar Biol Ecol 198:55-79
Fiala M, Cahet G, Jacques G, Neveux J, Panouse M (1976) Fertilization de communautés phytoplanctoniques. I. Cas d'un milieu oligotrophique Mediterranée nord-occidentale. J Exp Mar Biol Ecol 24:151-163

Grasshof K (ed) (1983) Methods of seawater analysis, 2nd edn. Verlag Chemie, Weinheim

Hein M, Rieman B (1995) Nutrient limitation of phytoplankton biomass or growth rate: an experimental approach using marine enclosures. J Exp Mar Biol Ecol 188:167-180

Jacques G, Cahet G, Fiala M, Panouse M (1973) Enrichissement de communautés phytoplanctoniques néritiques de Mediterranée nord occidentale. J Exp Mar Biol Ecol 11: $287-295$

Justic D (1987) Long term eutrophication of the northern Adriatic Sea. Mar Pollut Bull 18:281-284

Kemp WM, Boynton WR, Twilley RR, Stevenson JC, Means JC (1983) The decline of submerged vascular plants in upper Chesapeake Bay: summary of results concerning possible causes. Mar Technol Soc J 17:78-89

Koroleff F (1976a) Detemination of phosphorus. In: Grasshoff $\mathrm{K}$ (ed) Methods of seawater analysis. Verlag Chemie. Weiheim, p 125-130

Koroleff $\mathrm{F}$ (1976b) Detemination of ammonia. In: Grasshoff $\mathrm{K}$ (ed) Methods of seawater analysis. Verlag Chemie, Weiheim, p 150-156

Koroleff F (1976c) Determination of silicon. In: Grasshoff K (ed) Methods of seawater analysis. Verlag Chemie, Weiheim, p 174-180

Krom MD, Kress N, Brenner S (1991) Phosphorus limitation of primary productivity in the eastern Mediterranean Sea. Limnol Oceanogr 36:424-432

Legendre L, Rassoulzadegan F (1995) Plankton and nutrient dynamics in marine waters. Ophelia 41:153-172

Marbá N, Duarte CM (1997) Interannual changes in seagrass (Posidonia oceanica) growth and environmental change in the Spanish Mediterranean littoral. Limnol Oceanogr 42 : $800-810$

Marchetti R (1992) The problems of the Emilia Romagna coastal waters: facts and interpretations. In: Vollenweider RA, Marchetti R, Viviani R (eds) Marine coastal eutrophication. Sci Total Environ 1992(Suppl):21-33

Menzel DW, Case J (1977) Concept and design: controlled ecosystem pollution experiment. Bull Mar Sci 27:1-7

Mura MP, Agustí S, Cebrián J, Satta MP (1996a) Seasonal variability of phytoplankton biomass and community composition in Blanes Bay (1992-1994). In: Duarte CM (ed) Seasonality in Blanes Bay: a paradigm of the NW Mediterranean littoral. Publ Espec Inst Esp Oceanogr 22:23-29

Mura MP, Agustí S, del Girogio PA, Gasol J, Vaqué D, Duarte CM (1996b) Loss-controlled phytoplankton production in nutrient-poor littoral waters of the NW Mediterranean: in situ experimental evidence. Mar Ecol Prog Ser 130:213-219

Nixon SW, Pilson MEQ, Oviatt CA, Donaghay $P$, Sullivan B, Seitzinger S, Rudnick D, Frithsen J (1984) Eutrophication of a coastal marine ecosystem-an experimental study using the MERL microcosms. In: Fasham MJR (ed) Flows of energy and materials in marine ecosystems. Plenum Press, New York, p 105-135

Nixon SW, Oviatt CA, Frithsen J, Sullivan B (1986) Nutrients and productivity of estuarine and coastal marine ecosystems. J Limnol Soc S Afr 12:43-71

Oviatt CA, Lane P, French F III, Donaghay P (1989) Phytoplankton species and abundance in response to eutrophication in coastal marine mesocosms. J Plankton Res 11: $1223-1244$

Owens NJP, Rees AP, Woodward EMS, Mantoura RFC (1989) Size-fractionated primary production and nitrogen assimi- 
lation in the northwest Mediterranean Sea during January 1989. In: Martin JM, Barth $\mathrm{H}$ (eds) Proceedings of the EROS 2000 (European river-ocean system), Project Workshop. Commission of the European Communities Water Pollution Research, Paris, p 126-134

Parsons TR, Maita Y, Lalli CM (1984) A manual of chemical and biological methods for seawater analysis. Pergamon Press, Oxford

Provini A, Crosa G, Marchetti R (1992) Nutrient export from the $\mathrm{Po}$ and Adige river basins over the last 20 years. Sci Total Environ 1992(Suppl):291-312

Ray RT, Haas LW, Sieracki ME (1989) Autotrophic picoplankton dynamics in a Chesapeake Bay sub-estuary. Mar Ecol Prog Ser 52:273-285

Satta MP, Agustí S, Mura MP, Duarte CM (1996) Gross planktonic primary production in the Bay of Blanes (1992-1994). In: Duarte CM (ed) Seasonality in the Blanes Bay: a paradigm of the northwest Mediterranean littoral. Publ Espec Inst Esp Oceanogr 22:31-38

Schlüter L (1998) The influence of nutrient addition on growth rates of phytoplankton groups, and microzooplankton grazing in a mesocosm experiment. J Exp Mar Biol Ecol 228:53-71

Strathmann R (1967) Estimating the organic carbon content of phytoplankton from cell volume or plasma volume. Limnol Oceanogr 12:411-418

Thingstad TF, Rassoulzadegan F (1995) Nutrient limitation, microbial food webs and 'biological C pumps': suggested interactions in a P-limited Mediterranean. Mar Ecol Prog Ser 117:299-308

Editorial responsibility: Otto Kinne (Editor)

Oldendorf/Luhe, Germany
Thingstad TF, Zweifel UL, Rassoulzadegan F (1998) P limitation of heterotrophic bacteria and phytoplankton in the Northwest Mediterranean. Limnol Oceanogr 43:88-94

Tremblay JE, Legendre L (1994) Model for the size-fractionated biomass and production of the phytoplankton. Limnol Oceanogr 39:2004-2014

UNEP (United Nations Environment Programme) (1989) State of the Mediterranean marine environment. Mediterranean Action Plan Technical Report Series No. 28, UNEP, Athens

van Boekel WHM, Hansen FC, Riegman R, Bak RPM (1992) Lysis-induced decline of a Phaeocystis spring bloom and coupling with the microbial food web. Mar Ecol Prog Ser $81: 269-276$

Vaulot D, LeBot N, Marie D, Fukai E (1996) Effect of phosphorus on the Synechococcus cell cycle in surface Mediterranean waters during summer. Appl Environ Microbiol 62:2527-2533

Vidal M, Duarte CM, Sánchez MC (1999) Coastal eutrophication research in Europe: Progress and imbalances. Mar Pollut Bull 38:851-854

Waterbury JB, Watson SW, Valois FW, Franks DG (1986) Biological and ecological characterization of the marine unicelar cyanobacterium Synechococcus. In: Platt T, Li WKW (eds) Photosynthetic picoplankton. Can Bull Fish Aquat Sci 214:71-120

Yilmaz A, Bastürk Ö. Saydam C, Ediger D, Yilmaz K, Hatigplu E (1992) Eutrophication in Iskenderun Bay, northeastern Mediterranean. Sci Total Environ 1992(Suppl): $705-717$

Submitted: December 28, 1998; Accepted: September 20, 1999 Proofs received from author(s): March 9, 2000 